\title{
Attitude and coping before death: A current challenge for nurses in times of pandemic [Actitud $y$ afrontamiento ante la muerte: Un desafío actual para los profesionales de enfermería en tiempos de pandemia]
}

\author{
Alda Eliana Orihuela Castro*, Mónica Elisa Meneses-La Riva, Melitta Fidelia \\ Cosme Mendoza, Silvia Ofelia Soriano Ramos, María Gioconda Lévano \\ Cárdenas, Luis Javier Bazán Tanchiva \\ Instituto Nacional de Enfermedades Neoplásicas - Ministerio de Salud, Peru \\ *aldi.eliana@gmail.com
}

Received: 26 December 2020; Accepted: 30 December 2020; Published: 31 December 2020

\section{Resumen}

En la actualidad la pandemia ha provocado que los sistemas sanitarios colapsen por la alta demanda de pacientes con COVID 19 con un alto riesgo de mortalidad trayendo consigo dolor, sufrimiento y muerte. Objetivo: Determinar la relación entre la actitud y el afrontamiento del enfermero frente a la muerte del paciente oncológico con COVID-19 en la Unidad de Cuidados Críticos. Metodología: Enfoque cuantitativo, correlacional, de corte transversal y de diseño no experimental. La población conformada por un total de 65 profesionales de enfermería que laboran en la unidad de Cuidados Críticos. Se aplicó un instrumento sobre actitudes ante la Muerte CAM con 3 dimensiones: afectiva, conductual y cognitiva, con 33 ítems y la Escala de Bugen de Afrontamiento de la Muerte con 30 ítems ambas escalas de Likert. Los resultados evidencian que existe una correlación significativa 0,039 entre ambas variables y en el caso de la actitud del enfermero según las dimensiones: cognitivo, conductual, afectivo y afrontamiento sus correlaciones son: $0,521,0,719,0,015$ respectivamente. Se concluye que la actitud y el afrontamiento del profesional de enfermería frente a la muerte del paciente oncológico con COVID 19, asumen una postura de resiliencia para ofrecer cuidados enfermería continuos para asegurar, restaurar y salvaguarda la vida de la persona como una prioridad en su rol protagónico dentro del sistema sanitario basado en el compromiso y responsabilidad social a pesar de las amenazas de los riesgos ocupacionales existentes. Se sugiere ofrecer protección psicológica para disminuir los riesgos potenciales en la salud emocional y calidad de vida laboral.

Palabras clave: Actitud, Afrontamiento, Muerte, paciente oncológico con COVID-19 y profesional de enfermería.

\footnotetext{
Abstract

Currently the pandemic has caused health systems to collapse due to the high demand of patients with VOC 19 with a high risk of mortality bringing with it pain, suffering and death. Objective: To determine the relationship between a nurse's attitude and coping with the death of a cancer patient with COVID-19 in the Critical Care Unit. Methodology: Quantitative, correlational, crosssectional and non-experimental design approach. The population is made up of a total of 65 nursing professionals who work in the Critical Care Unit. An instrument was applied on attitudes towards death CAM with 3 dimensions: affective, behavioral and cognitive, with 33 items and the Bugen Scale for facing death with 30 items, both Likert scales. The results show that there is a significant correlation 0.039 between both variables and in the case of the nurse's attitude according to the dimensions: cognitive, behavioral, affective and coping, their correlations are:
} 


\section{GMS \\ Journal of Global Health and Medicine}

Vol. 4, $\mathbf{N}^{\circ} 2,2020$

Copyright @ 2020, CINCADER.

ISSN 2523-9511

DOI: https://doi.org/10.32829/ghmj.v4i2.204

$0.521,0.719,0.015$ respectively. It is concluded that the attitude and the coping of the nursing professional in the face of the death of the cancer patient with COVID 19, assume a posture of resilience to offer continuous nursing care to ensure, restore and safeguard the life of the person as a priority in their leading role within the health system based on commitment and social responsibility despite the threats of existing occupational risks. It is suggested to offer psychological protection to diminish the potential risks in the emotional health and quality of work life.

Keywords: Attitude, coping, death, cancer patient with COVID-19, nursing professional.

\section{Introduction}

The coronavirus is an unknown virus but its origin was in December 2019, in the city of Wuhan (China). The first case was confirmed in the United States and then in Brazil where the number until June in Europe has been reported 2,378,958 cases and 187,468 deaths, while the incidence of infected and deaths is increasing 3,638,525 (49\%) cases of COVID-19 and 196,440 (46\%) deaths; where the highest incidence of confirmed cases and deaths are observed are 5 countries worldwide and these are Brazil, United States of America, Chile, Mexico and Peru (OMS, 2020). The usual symptoms of COVID-19 are fever, dry cough and other less frequent symptoms of tiredness, body aches, nasal congestion, headache, conjunctivitis, sore throat, diarrhea, loss of taste or smell and skin rashes or color changes in the fingers and toes (MINSA,2020). It should be noted that person-to-person contact increases the risk and possibility of becoming infected with respiratory tract infections through droplets coming out of a person's nose or mouth when coughing, sneezing or talking. These droplets can land on objects and surfaces around the person such as tables, doorknobs, etc. and if the person touches another person and then picks up their nose, mouth, eyes, hand washing is recommended. The person who becomes infected with COVID-19 can die quickly with difficulty breathing basically and the population at greatest risk are people over 60 years old, people with high blood pressure, heart and lung problems, diabetes, asthma and cancer (OMS,2020). That is why the World Health Organization (WHO), recommends isolation and maintaining 1 meter distance for everyone and the use of masks such as hand washing (OMS, 2020).

In this regard, the WHO reports that the world's population of professional nursing workers represents almost half of all health workers. The role of the nurse is crucial in the health care setting to provide comprehensive and holistic care services to patients in order to achieve effective treatment, recovery, and rehabilitation of health. In the critical areas of hospital services, there is a high risk of patient death due to the deterioration of their health condition (4). In addition, nurses are identified as a critical linchpin in the health care response to infectious disease pandemics and epidemics, but their direct contact with death in patients with VOC-19 results in the depletion and loss of the nursing workforce (OMS,2020), (Jackson y Usher, 2020).

This health situation makes the patient feel vulnerable and fragile in the presence of pain, suffering and death, as well as fearing the possibility of losing their lives. The process of caring for the patient in the critical areas requires high professional nursing competencies such as cognitive, procedural and attitudinal to provide support to help stabilize and recover the patient's health status throughout the process of care interventions. The nurse interacts with various emotional responses of the patient that in most cases can be negative and that generate a negative impact on the patient's health (Gonzales, 2015)

In the critical care units, situations of high risk and uncertainty in the clinical evolution of the patient can become evident. Death is a biological and psychosocial process in which vital functions inevitably disappear in a gradual and silent sequence, generally escaping simple observation (Jackson y Usher,2020). The death is the conclusion of an earthly and historical existence of the 


\section{GMS \\ Journal of Global Health and Medicine}

Vol. 4, $\mathbf{N}^{\circ} 2,2020$

Copyright @ 2020, CINCADER.

ISSN 2523-9511

DOI: https://doi.org/10.32829/ghmj.v4i2.204

man, symbol of the finality of the being, that suffered in an impotent and passive form is not in the hands of the man to be able to avoid it. With it the fundamental biological processes end, but also the social relations of man (Gonzales, 2015)

Therefore, health professionals, especially nursing professionals, have to deal with unexpected situations. The attitude and confrontation of the nursing professional with the process of death is a fundamental element for the management and care of the patient in these critical areas. Death in critical services such as Intensive Care and Intermediate Therapy Units occurs daily in the practice of the nursing professional. It is a unique event and very difficult to face for the professional, as well as for the family of the loved one who has just died. And the nursing professional has within his or her functions to face this transition step from life to death. A warm, favorable and supportive attitude towards the family is expected (De Arco-Canoles, Suarez-Calle, 2018)

Understanding that attitude is the behavior in front of a certain situation, and this is reflected through the soul life of each human being (García-Avendaño, Ochoa-Estrada, BriceñoRodríguez,2018). Attitude has three dimensions, which are: cognitive, affective and behavioral. The nurse must have the abilities and skills to recognize that the patient is in a process of life deterioration approaching a path of death, for which it is required to continue making efforts to achieve an integral care where the satisfaction of basic needs is prioritized, well-being as a dignified death (De Arco-Canoles, Suarez-Calle, 2018)

In relation to the Cognitive it is the set of data and information that the subject knows about the object from which he takes his attitude. It is formed by the perceptions and beliefs towards an object, as well as by the information we have about an object. In the affective: they are the sensations and feelings that this object produces in the subject, is the feeling for or against a social object. It is the most characteristic component of attitudes. Here lies the main difference with the beliefs and opinions that are characterized by their cognitive component (GarcíaAvendaño, Ochoa-Estrada, Briceño-Rodríguez,2018). In the affective-emotional sphere, it is to experience emotional reactions, linked to the beliefs and values that result from the evaluation of the responses; good, bad, just, unjust, this component can be associated with cognitive or behavioral characteristics and is susceptible to empirical measurement based on physiological reactions and verbal responses of the subjects, that is, that they are influenced by the feelings that the object awakens in the individual.

As for the behavioral one: they are the intentions, dispositions or tendencies towards an object, it is when a true association between object and subject arises. It is the tendency to react towards objects in a certain way. It is the active component of the attitude.(Espinoza-Venegas, LuengoMachuca, Sanhueza-Alvarado, 2016) Thus, the attitude that the nursing professional has in the face of the death of the patient has much to do with humanized care including in the process of death. For this reason Watson $\mathrm{J}$, invites us to continue strengthening to seek harmony between the mind, body and soul, acquiring a deeper dimension. And to face death with a positive attitude (Sánchez, Valderrama, Vilca, 2016)

Coping is a set of cognitive and behavioral strategies that the nurse reflects on in patient care. Nursing coping with death is of great importance because of the way it influences the interpersonal relationship and the care of both patients and families. The death of a nursing professional generates many emotions and therefore will be reflected in attitudes and coping, this could affect the emotional health of the professional as Burnout syndrome and therefore lower work performance and affect their quality of work life (Cabanach, Valle, Rodríguez, Piñeiro, Freire, 2010). On the other hand, the coping capacity will be positive when the nurse has more experience or training in relation to the care expertise about the death process (GarcíaAvendaño, Ochoa-Estrada, Briceño-Rodríguez,2018). 


\section{GMS \\ Journal of Global Health and Medicine}

Vol. 4, $\mathbf{N}^{\circ}$ 2, 2020

In the case of coping, it refers to any activity that the individual can carry out, both of a cognitive and behavioral type, in order to face a certain situation (Cabanach,Valle, Rodriguez,Piñero Freire, 2010). Coping is associated with stress as harmful, threatening and/or challenging, and another moment of secondary evaluation in which the situation is re-evaluated and one's own resources to face it are also assessed. Coping has cognitive, affective and behavioral components. One learns what to think, what to feel and what to do with respect to the process and care at the end of life, that is, a favorable or unfavorable response is observed that would be related to sociodemographic characteristics, such as personality traits, as personal or behavioral beliefs. Thus, the theory of human care guides the nursing professional to develop effective, authentic and empathic interrelationships that will allow him/her to be prepared for positive and negative feelings in the face of a situation of death during professional practice (García-Avendaño, OchoaEstrada, Briceño-Rodríguez,2018).

International studies in Mexico conclude that nurses are prepared to care for life, considering that, on a general level, they accept death as an inevitable fact. Nevertheless, from the professional perspective of the nursing personnel, the death is considered a relief, when seeing the burden that the relatives of the patient evidence in their final process. De Freitas, Banazeski, Eisele, De Souza, Bitencourt, Souza (2016) maintains that the qualification of nurses in their training process in the face of death and dying is deficient in the learning of professionals for the process of death and dying, causing suffering to the nursing team, which influences the quality of care provided to patients and their families. In Colombia, Cáceres, Cristancho, López (2019), indicate that nurses have attitudes towards death with predominance of acceptance of approach in ICUs.

For Flores, Castro, and Quipildor(2019). the attitudes experienced by ICU nurses regarding the death of patients depend on factors related to the age of the patient, the bond created, and the pathology of the patient generating these different feelings and attitudes. The tools used to face this situation are scarce, causing stress in the work environment. The attitude towards palliative care is centered on the care of dignity, the satisfaction of the patient's needs and the containment of the patient and the family. For Cuarite, Reynoso, Távara (2017). it is argued that older nurses have a lower percentage of coping skills than younger staff, suggesting emotional support for quality care at the end of death.

For Flores, Castro and Quipildor (2019). maintains that the attitudes experienced by nurses in the intensive care unit with respect to the death of patients depend on factors related to the age of the patient, the bond created and the pathology of the patient generating these different feelings and attitudes. The tools used to face this situation are scarce, causing stress in the work environment. The attitude towards palliative care is centered on the care of dignity, the satisfaction of the patient's needs and the containment of the patient and the family. For Cuarite, Reynoso, Távara (2017), it is argued that older nurses have a lower percentage of coping skills than younger staff, suggesting emotional support for quality care at the end of death.

In this sense, Bueno and Barrientos-Trigo (2020). maintain that the role of the nursing professional as a key element in the containment of the patient who suffers from high stress marked by the pressure of care and the lack of means of protection. In view of this tension, it is relevant to analyze the emotional impact of health professionals during the coronavirus pandemic and the coping resources to diminish or attenuate this impact where stress, sleep disorders and depressive symptoms stand out. It is suggested to provide the health personnel with psychological protection since to take care of oneself.

Likewise, in this same country in a study it was reported that one third of the nursing professionals present a bad coping with death, in their professional training has been inadequate to provide 


\section{CMS Journal of Global Health and Medicine}

Vol. 4, $\mathbf{N}^{\circ} 2,2020$

ISSN 2523-9511

DOI: https://doi.org/10.32829/ghmj.v4i2.204

final care to the terminal patient and they do not have psychological support from the institution( Marchan, 2015).

On the other hand, Oblitas, Pérezand Gonzales (2016), indicate that the feelings revealed by the nurse in the care of the oncological patient in the terminal phase are expressed by sadness, impotence and frustration in the face of the degenerative process of the patient and the pain of the family member; in spite of this, the nurse provides care to ensure a dignified death. Likewise, Bastos, Quintana and Carnevale (2017) shows that nursing professionals in the face of a patient's death experience the meaning of impotence, sadness and despair. Likewise, Niño de Guzmán, Portilla and Rojas (2018), expresses that in the face of death health personnel experience positive attitudes as well as negative ones, and an indifferent attitude is related to the service.

Likewise, Fernandez, Garcia and Lozano (2018), in Spain maintains that death is a natural aspect of life and does not believe that the solution to life's problems is death. Greater psychological support would improve both the attitude and the coping of the nursing staff which would lead to better care for patients and families. In this same line, Manrique (2018), argues the need to incorporate a specific program is effective about death and its process, to change the attitudes of health personnel when they have to face death. In China, Shi Y, Wang J, Yang Y, Wang Z, Wang G, Hashimoto K, et al. (2020), suggests that greater attention should be paid to the knowledge and attitudes of both doctors and nurses in hospitals during the outbreak of COVID-19.

Given this panorama, the attitude and confrontation that the nurse manifests in the critical care unit during the death of the oncological patient with COVID-19; this event generated diverse feelings of frustration and despair to be able to satisfy basic needs, support and accompany the patient and family even in the family interaction that is only through telephones to know about his general state or to say goodbye because he is in the process of dying, it is sad to see someone die alone; very difficult to witness (MINSA,2020)

Finally, health professionals have been responding to the health problems caused by the COVID pandemic. 19 Health professionals have a responsibility to preserve and maintain the health and lives of patients. However, the high demand of patients with COVID-19 has caused services to collapse because of the number of patients. Therefore, it is important to evaluate the attitude and the coping of the nurse with the death of the cancer patient with COVID-19 in the critical units; there is no doubt that this situation has generated an impact in the physical and mental health of the health personnel, especially in the nurses. Therefore, it is necessary to protect and give a psychological support that mitigates the potential risks of the quality of life as well as of their emotional health.

\section{Methodology}

The study is quantitative, correlational, cross-sectional and non-experimental design approach (Hernández, Fernández and Baptista, 2014). The population was made up of a total of 65 nursing professionals working in the Critical Care Unit of a specialized cancer institution. It was applied a CAM 10 instrument (questionnaire of attitudes before death), a Cuban version adapted for the study. It consists of 33 questions divided into 3 dimensions such as: cognitive, affective and behavioral. This instrument consists on positive questions $(1,2,3,4,7,8,9,10,11,17,19,20$, $21,22,23,24,32,33)$ which were granted a score of (1) for each answer "in agreement" and in the negative questions $(5,6,12,13,14,15,16,18,25,26,27,28$ 29,31) it was granted (zero) points for each answer "in disagreement". The scores are then added up and the type of attitude of the respondents is determined according to the score obtained 10-12 points: Positive attitude towards the death of the patient COVID-19 and 0-8 points: Negative attitude towards the death of patient COVID-19. the Bugen Scale of Coping with Death with 30 items both scales with a Likert scale. 
Vol. 4, $\mathbf{N}^{\circ} 2,2020$

\section{Journal of Global Health and Medicine}

Copyright (C) 2020, CINCADER.

ISSN 2523-9511

DOI: https://doi.org/10.32829/ghmj.v4i2.204

For the study the instrument was adapted and validated by 5 expert judgments made by a multidisciplinary team of 3 nurses and 2 psychologists. In addition, a pilot test was carried out where a Cronbach's Alpha of 0.820 was obtained. For data collection, the informed consent of all participants was requested. The data were introduced in a database in the SPSS v.25 program, to carry out the descriptive analysis of the results that allow us to have an exact account of percentages of the calculation of the analyzed variable. The results are shown in tables and graphs.

\section{Results}

Table 1. Socio-demographic characteristics of the nurse - Institute specialized in cancer

\begin{tabular}{|c|c|c|c|}
\hline \multicolumn{2}{|c|}{ Socio-demographic characteristics } & Frequency & Percentage \\
\hline \multirow{3}{*}{ Sex } & Male & 4 & 6.2 \\
\hline & Female & 61 & 93.8 \\
\hline & Total & 65 & 100.0 \\
\hline \multirow{5}{*}{ Age } & 20 a 30 Years & 26 & 40.0 \\
\hline & 31 a 40 Years & 31 & 47.7 \\
\hline & 41 a 50 Years & 7 & 10.8 \\
\hline & 51 a 60 Years & 1 & 1.5 \\
\hline & Total & 65 & 100.0 \\
\hline \multirow{5}{*}{ Civil Status } & Single & 34 & 52.3 \\
\hline & Married & 26 & 40.0 \\
\hline & Separate & 4 & 6.2 \\
\hline & Widow & 1 & 1.5 \\
\hline & Total & 65 & 100.0 \\
\hline \multirow{4}{*}{ Religion } & Catholic & 58 & 89.2 \\
\hline & Evangelical & 5 & 7.7 \\
\hline & Others & 2 & 3.1 \\
\hline & Total & 65 & 100.0 \\
\hline \multirow{3}{*}{ Professional experience } & $0-5$ years & 25 & 38.5 \\
\hline & 6 years in addition & 40 & 61.5 \\
\hline & Total & 65 & 100.0 \\
\hline \multirow{3}{*}{ Psychological support } & Yes & 2 & 3.1 \\
\hline & No & 63 & 96.9 \\
\hline & Total & 65 & 100.0 \\
\hline
\end{tabular}

It was found that in Gender: 93.8\% were female and 6.2\% male. Age: The highest percentage of nurses was from $31-40$ years old in $47.7 \%$ and the lowest was from $51-60$ years old in $1.5 \%$. Marital Status: The highest percentage of nurses were single (52.3\%) and widowed (1.5\%). Religion: The highest percentage of nurses were Catholic at $89.2 \%$ and other $3.1 \%$. Professional Experience: The highest percentage of nurses were 6 years or older at $61.5 \%$ and the lowest at 0-5 years at $38.5 \%$. Psychological support was only $3.1 \%$ of nurses and $96.9 \%$ did not receive psychological support. 
Vol. 4, $\mathrm{N}^{\circ} 2,2020$

Copyright @ 2020, CINCADER.

ISSN 2523-9511

DOI: https://doi.org/10.32829/ghmj.v4i2.204

Table 2. Attitude and coping of the nurse in the face of the death of the cancer patient with COVID19 in the critical units of a specialized cancer institute.

\section{Correlation}

\begin{tabular}{lllr|r} 
& & Attitude & \multicolumn{1}{c}{ Coping } \\
\hline Rho by Spearman & Attitude & Correlation Coefficient & 1.000 &, $257^{*}$ \\
& & & \\
& & Sig. (bilateral) & 65 & 0.039 \\
\cline { 2 - 4 } & $\mathrm{N}$ &, $257^{*}$ & 1.000 \\
\cline { 2 - 5 } & Coping & Correlation Coefficient & 0.039 & \\
\cline { 2 - 4 } & Sig. (bilateral) & 65 & 65 \\
\hline
\end{tabular}

${ }^{*}$. The correlation is significant at the 0.05 level (bilateral).

Centre of Research and Training for Regional Development Online at www.journals.cincader.org

The value of Sig 0.039 being found that there is a weak relationship between attitude and coping of the nurse with the death of the patient with COVID-19 in Critical Units rejecting the null hypothesis and accepting the alternate hypothesis.

Table 3. Cognitive and coping of the nurse in the face of the death of the cancer patient with COVID-19 in the critical units of a specialized cancer institute.

\section{Correlaciones}

\begin{tabular}{lllr|r} 
& & cognitivo & afrontamiento \\
\hline Rho by Spearman & cognitivo & Correlation & 1.000 & 0.081 \\
& & Coefficient & & \\
\cline { 2 - 4 } & Sig. (bilateral) & 65 & 0.521 \\
\hline & $\mathrm{N}$ & 0.081 & 65 \\
\cline { 2 - 4 } & Coping & Correlation & & 1.000 \\
& & Coefficient & 0.521 & \\
\cline { 2 - 4 } & Sig. (bilateral) & 65 & 65 \\
\hline
\end{tabular}

The value of Sig 0.521 , finding that there is a relationship between cognitive attitude and coping with the death of the patient with COVID-19 in Critical Care Units, rejecting the alternative hypothesis and accepting the null hypothesis.

Table 4. Behavior and coping by nurses in the face of the death of cancer patients with COVID19 in the critical units of an institute specializing in cancer.

\section{Correlaciones}

\begin{tabular}{|c|c|c|c|c|}
\hline \multirow{7}{*}{ Rho by Spearman } & & & Conductual & afrontamiento \\
\hline & Behavioral & $\begin{array}{l}\text { Correlation } \\
\text { Coefficient }\end{array}$ & 1.000 & -0.046 \\
\hline & & Sig. (bilateral) & & 0.719 \\
\hline & & $\mathrm{N}$ & 65 & 65 \\
\hline & Coping & $\begin{array}{l}\text { Correlation } \\
\text { Coefficient }\end{array}$ & -0.046 & 1.000 \\
\hline & & Sig. (bilateral) & 0.719 & \\
\hline & & $\mathrm{N}$ & 65 & 65 \\
\hline
\end{tabular}

The value of Sig 0.719 , finding that there is a relationship between behavioral attitude and the nurse's coping with the death of the patient with COVID-19 in Critical Care Units, rejecting the alternative hypothesis and accepting the null hypothesis. 
Table 5. Affective attitude and coping by nurses in the face of the death of cancer patients with COVID-19 in the critical units of an institute specializing in cancer.

\section{Correlaciones}

\begin{tabular}{|c|c|c|c|c|}
\hline \multirow{7}{*}{ Rho by Spearman } & & & afectivo & afrontamiento \\
\hline & affective & $\begin{array}{l}\text { Correlation } \\
\text { Coefficient }\end{array}$ & 1.000 &, $300^{*}$ \\
\hline & & Sig. (bilateral) & & 0.015 \\
\hline & & $\mathrm{N}$ & 65 & 65 \\
\hline & Coping & $\begin{array}{l}\text { Correlation } \\
\text { Coefficient }\end{array}$ &, $300^{*}$ & 1.000 \\
\hline & & Sig. (bilateral) & 0.015 & \\
\hline & & $\mathrm{N}$ & 65 & 65 \\
\hline
\end{tabular}

${ }^{\star}$. The correlation is significant at the 0.05 level (bilateral).

The value of Sig 0.015 being found that there is a weak relationship between the affective attitude and the nurse's coping with the death of the patient with COVID-19 in Critical Care Units, rejecting the null hypothesis and accepting the alternative hypothesis.

\section{Discussion y conclusions}

According to the study carried out to determine the relationship between attitude and coping of the nurse with the death of the patient with COVID-19 in critical units, it was found that there is a weak correlation between attitude and coping of the nurse with the death of the patient with COVID-19 in critical units; accepting the alternative hypothesis. These results can be compared with the study by Araujo, García and García-Navarro (2020). Those who argue that the process of death in times of COVID19, emotionally affected health workers especially nurses who live the experience of working directly with situations of sadness and pain. Nursing care in critical areas deals with the process of death of patients and the suffering of family members.

It follows that intervention during loss and grief is a competence of the nursing professional, since it provides comprehensive care of accompaniment and even spiritual care. Currently, the pandemic has made it possible to clarify the need to fill the gaps of knowledge about the management and coping with the process of death in critical areas. The positive attitude assumed by the nurse will not only benefit the patient but also the nursing professionals in their self-care. Thus, effective coping and mourning preparation is not only needed by patients and family but also by health professionals.

Relationship between cognitive attitude and the nurse's coping with the death of the patient with COVID-19 in Critical Care Units at the National Institute of Neoplastics. The results found were that there is no correlation between both variables. These results can be compared with the Gonzales study (2016), which indicates that the cognitive attitude favorable to the death of a patient, have knowledge about the care of the dying patient, which they acquire in professional experience, but consider that the knowledge acquired during professional training is not sufficient to provide quality care to patients and their families in the face of death.

It is concluded that it is necessary that during the professional training courses or subjects are taught that allow the patient to deal with and approach the death process from an interdisciplinary approach for direct communication for the patient-family. It is impossible to use virtual strategies for effective communication with skills to be able to communicate and provide preventive emotional support in the approach to mourning (Palacios, Santos, Velázquez y León, 2020). It should be noted that in times of pandemic the impact of dizzying and unknown events on the health status of patients was an obstacle for nursing professionals to comply with protocols 


\section{GMS \\ Journal of Global Health and Medicine}

Vol. 4, $\mathbf{N}^{\circ} 2,2020$

Copyright @ 2020, CINCADER.

ISSN 2523-9511

DOI: https://doi.org/10.32829/ghmj.v4i2.204

according to the rules established in cancer patients in the terminal phase. The management of the oncological patient with COVID-19 was initially uncertain, since the fear, dread and uncertainty of the high risk of contagion resulted in a change of paradigm and attitude for the management of death by the nursing professional, producing emotional and physical effects, among others.

Regarding the relationship between behavioral attitude and the nurse's coping with the death of the patient with COVID-19 in Critical Care Units at the National Institute of Neoplastics. The results found do not show any relationship between behavioral attitude and coping. These results can be compared with the study by Gonzales (2016), which indicates a favorable attitude with a tendency to be unfavorable in the face of a patient's death. It is favorable because they recognize that the nurse must seek a dignified death; provide psychological support to the family; inform, console, listen and act with sensitivity, and unfavorable because some professionals are afraid of facing death, showing a distant attitude.

It is concluded that the behavior assumed by the nurse is related to the impact of the situation lived in the services of critical areas generating an attitude of rejection therefore a confrontation is evasive. It should be noted that nursing professionals require emotional and psychological support to cope with the difficulties inherent to the pandemic as lack of human resources, material protection, among others.

This is confirmed by Shen, Zou, Zhong, Yan and Li (2020), who say that it is the nurse who assumes this care by experiencing workload, long-term fatigue, threat of infection and frustration over the death of the patients they care for. It was found that intensive care unit nurses who saw patients with VOC-19 die in greater numbers than usual manifested decreased appetite, fatigue, difficulty sleeping, nervousness, frequent crying and even suicidal thoughts especially young nurses with no experience in caring for the critically ill patient faced a greater psychological crisis. If this psychological crisis is not effectively resolved, it will not only lead to decreased immunity and increased likelihood of VIDOC-19 infections, but it also has an adverse impact on the quality and safety of the care system.

Establishing the relationship between affective attitude and coping of the nurse in the face of the death of the cancer patient with COVID-19 in Critical Care Units at the National Institute of Neoplastics results in a weak relationship between affective attitude and coping of nurses. These results can be compared with the Gonzales study (2016), which indicates that the unfavorable attitude with a tendency to favor death, expressed in a state of psychological indifference, thus responding poorly to aspects of emotional life; they feel fear and would prefer not to care for a dying patient.

It is concluded that the continuing education and training of nursing professionals on the management and care of the dying patient are indispensable elements in offering safe care and preventing coping difficulties, such as conflicting information, conflicting diagnoses, or unfounded hope. In short, the end of the life process generates in the patient and the family a set of reactions to which health personnel must respond. The role of the nurse in the face of the death process is one of accompaniment, which requires specific competencies that address this process in an integral and individualized manner.

Finally, the situation of isolation suffered by patients affected by this pandemic makes it even more difficult for the family to adapt during the mourning process (Shen, Zou, Zhong, Yan and Li ,2020). On the other hand, the efforts of the nursing professionals who provide care during these difficult times have caused occupational problems for the nurses who are unable to adapt to the different mechanisms for coping with death or who are unable to find meaning and compassion in this situation that they have had to live through (Espinoza, Luengo-Machuca and SanhuezaAlvarado ,2016) (Villanueva, Uriarte and Carhuajulca,2015). It is important to manage 
Vol. 4, $\mathbf{N}^{\circ} 2,2020$

psychological interventions and occupational medical assessments to decrease the impact of the pandemic on the quality of working life of nurses in critical areas.

\section{References}

Araujo M., García S., García-Navarro B. Abordaje del duelo y de la muerte en familiares de pacientes con covid-19: revisión narrativa, Enfermería Clínica (2020). doi: https://doi.org/10.1016/j.enfcli.2020.05.011

Bastos, R. Quintana,A. Carnevale F. Vivências dos enfermeiros frente ao processo de morrer: uma metassíntese qualitativa. Revista Portuguesa de Enfermagem de Saúde Mental [Internet]. 2017; (17):58-64. http://dx.doi.org/10.19131/rpesm.0184.

Bueno M, y Barrientos-Trigo S. Cuidar al que cuida: el impacto emocional de la epidemia de coronavirus en las enfermeras y otros profesionales de la salud. Enferm Clin. 2020 May 16 Spanish. doi: 10.1016/j.enfcli.2020.05.006

Cáceres D., Cristancho L., López L. Actitudes de las enfermeras frente a la muerte de los pacientes en una unidad de cuidados intensivos. Rev Cienc Salud. 2019;17(3):98-110. Doi: http://dx.doi.org/10.12804/revistas.urosario.

Cabanach, G., Valle, A., Rodríguez, S., Piñeiro, L., Freire, C. Escala de afrontamiento del estrés académico (A-CEA). Revista Iberoamericana de Psicología y Salud [Internet]. 2010; 1 (1): 51-64. Recuperado de: https://www.redalyc.org/articulo.oa?id=245116411005

Cuarite L., Reynoso, M., Távara, R. Actitud del enfermero frente a la muerte en el servicio de emergencia de un hospital. [Academic work]. Lima: Universidad Cayetano Heredia; 2017.

De Freitas, T., Banazeski, A., Eisele, A., De Souza, E., Bitencourt, J., Souza, S. La visión de la Enfermería ante el Proceso de Muerte y Morir de pacientes críticos: una revisión integradora. Enfermería Global, 2016, 15(41), 322-334. http://scielo.isciii.es/scielo.php?script=sci arttext\&pid=S169561412016000100015\&lng=es.

De Arco-Canoles O., Suarez-Calle Z. Rol de los profesionales de enfermería en el sistema de salud colombiano. Univ. Salud. 2018; 20(2):171-182. DOI: http://dx.doi.org/10.22267/rus.182002.121

Espinoza-Venegas M, Luengo-Machuca L, Sanhueza-Alvarado O. Actitudes en profesionales de enfermería chilenos hacia el cuidado al final de la vida. Análisis multivariado. Aquichan. 2016;16(4):430-46.

Fernández J., García L. Lozano T; Actitudes y afrontamiento ante la muerte en el personal de enfermería (2018) 25-31.

Fernández J., Martínez L., García-Bueno M., Grande A., González T., Prieto A. Actitudes y afrontamiento ante la muerte en el personal de enfermería. Tiempos de enfermería y salud. Tiempos de Enfermería y Salud. 2017; 1(2):29-35.

Flores G., Castro R. y Quipildor, R. Actitud del personal de enfermería ante la muerte de pacientes en la unidad de cuidados intensivos. 2019. file://C:/Users/ASUS/Desktop/26320-Texto\%20del\%20art\%C3\%ADculo-77690-1-1020191108.pdf

García-Avendaño D., Ochoa-Estrada M., Briceño-Rodríguez I. Actitud del personal de enfermería ante la muerte de la persona en la unidad de cuidados intensivos: estudio cuantitativo. Duazary. 2018; 15(3): 281-293. Doi: http://dx.doi.org/10.21676/2389783X.2421

Gonzales H. Actitud del profesional de enfermería ante la Muerte de un paciente. Hospital general de jaén 2016. http://repositorio.unc.edu.pe/bitstream/handle/UNC/935/T016_47191324_T.pdf?sequenc $\mathrm{e}=1$ \&

González C. Competencias profesionales en enfermeras que desempeñan su labor en una unidad de cuidados intensivos. Rev. iberoam. Educ. investi. Enferm. 2015; 5(1):35-46. 
https://www.enfermeria21.com/revistas/aladefe/articulo/149/competencias-profesionalesen-enfermeras-que-desempenan-su-labor-en-una-unidad-de-cuidados-intensivos/

Hernández S. Fernández C. Baptista F Metodología de la Investigación 2014.

Jackson D. y Usher K. COVID-19: Resiliencia y la Fuerza Laboral de los Profesionales de Enfermería. Investigación en Enfermería: Imagen y Desarrollo, vol. 22, 2020. Pontificia Universidad Javeriana. https://revistas.javeriana.edu.co/filesarticulos/IE/22\%20(2020)/145263339002/145263339002_visor_jats.pdf

Marchán E. Afrontamiento del profesional de enfermería ante la muerte de pacientes, en unidades de paliativos y oncología dic 2014 - 2015 (España)

Manrique M. Miedo, ansiedad y afrontamiento ante la muerte en estudiantes de enfermería: efectos de un programa de formación. BIGBANG [Internet]. 23 july 2018 https://revistas.unjfsc.edu.pe/index.php/BIGBANG/article/view/210

MINSA: Casos confirmados por Coronavirus COVID-19 ascienden a 123979 en el Perú (Comunicado $\mathrm{N}^{\circ}$ 111) [Internet]. https://www.gob.pe/institucion/minsa/noticias/165699minsacasos-confirmados-por-coronavirus-covid-19-ascienden-a-123-979-en-elperucomunicado-n-111

Niño de Guzmán R. Portilla R. y Rojas R. Actitud del profesional de enfermería frente a la muerte en la unidad de cuidados intensivos en un Hospital nacional, 2018.

http://repositorio.upch.edu.pe/bitstream/handle/upch/3521/Actitud_NinodeGuzmanRivero s_Mayra.pdf?sequence=1\&isAllowed=y

Oblitas C, Pérez S, Gonzales D. Actitudes de las enfermeras en el cuidado al paciente con cáncer en etapa terminal atendido en un Hospital de Chiclayo. 2016; 2(2). http://revistas.uss.edu.pe/index.php/SVS/article/view/203

Organización Mundial de la Salud. La OMS caracteriza a COVID-19 como una pandemia 2020. https://www.paho.org/es/noticias/11-3-2020-oms-caracteriza-covid-19-como-pandemia

Organización Mundial de la Salud. Informes de situación de la COVID-19. 2020. https://www.paho.org/es/informes-situacion-covid-19

Organización Mundial de la Salud. La OMS y sus asociados hacen un llamamiento urgente para que se invierta en el personal de enfermería. 2020. https://www.who.int/es/news/item/0704-2020-who-and-partners-call-for-urgent-investment-in-nurses

Palacios M., Santos E, Velázquez M., y León M. COVID-19, a worldwide public health emergency [in Spanish, una emergencia de salud pública mundial]. Rev Clin Esp. 2020; S00142565(20)30092-8. doi:10.1016/j.rce.2020.03.001

Sánchez L. Valderrama F. Vilca E. Actitud del enfermero de emergencia ante la muerte. :18-26. 2016. http://repositorio.upch.edu.pe/handle/upch/750?locale-attribute=en

Shen X, Zou X, Zhong X, Yan J, Li L. Psychological stress of ICU nurses in the time of COVID19 China 2020. DOI 10.1186/s13054-020-02926-2

Shi Y, Wang J, Yang Y, Wang Z, Wang G, Hashimoto K, et al. Knowledge and attitude of medical staff in Chinese psychiatric hospitals regarding COVID-10 Journal homepage 2020 doig.org/10.1016/ j.bbih.2020.100064

Villanueva C., Uriarte S., Carhuajulca D. Actitudes de las enfermeras en el cuidado al paciente con cáncer en etapa terminal atendido en un Hospital de Chiclayo. Salud \& Vida Sipanense. 2015;2(2):30-44. 